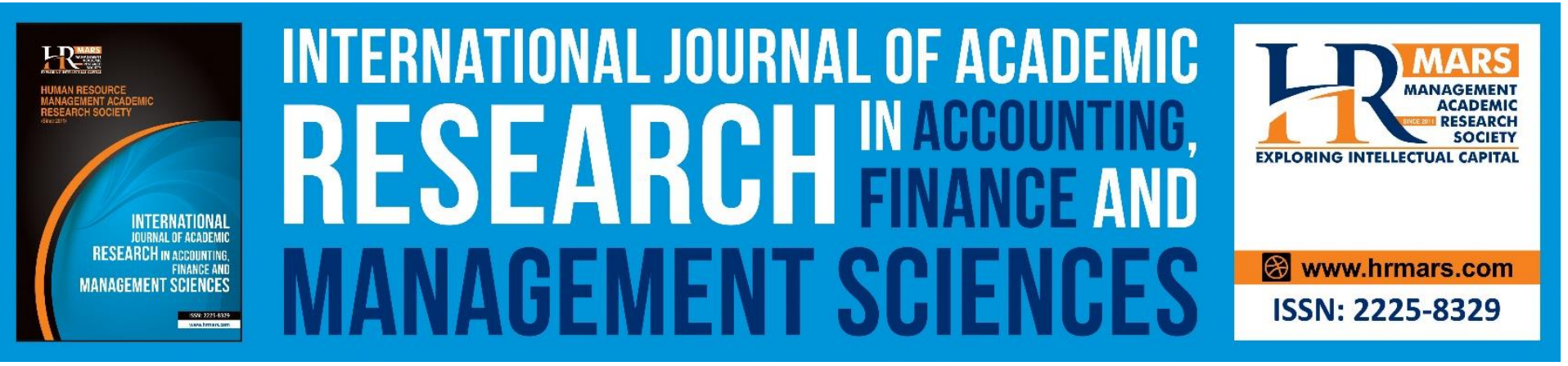

\title{
The Effect of IFRS Adoption on Corporate Performance of Listed Firms in Nigeria
}

Christopher Ifeanyichukwu Nwufo, Mmanuel Ib Chima

To Link this Article: http://dx.doi.org/10.6007/IJARAFMS/v11-i3/10575 DOI:10.6007/IJARAFMS /v11-i3/10575

Received: 14 June 2021, Revised: 17 July 2021, Accepted: 29 July 2021

Published Online: 13 August 2021

In-Text Citation: (Nwufo \& Chima, 2021)

To Cite this Article: Nwufo, C. I., \& Chima, M. I. (2021). The Effect of IFRS Adoption on Corporate Performance of Listed Firms in Nigeria. International Journal of Academic Research in Accounting Finance and Management Sciences, 11(3), 1-18.

Copyright: (c) 2021 The Author(s)

Published by Human Resource Management Academic Research Society (www.hrmars.com)

This article is published under the Creative Commons Attribution (CC BY 4.0) license. Anyone may reproduce, distribute, translate and create derivative works of this article (for both commercial and non-commercial purposes), subject to full attribution to the original publication and authors. The full terms of this license may be seen at: http://creativecommons.org/licences/by/4.0/legalcode

Vol. 11, No. 3, 2021, Pg. 1 - 18

http://hrmars.com/index.php/pages/detail/IJARAFMS

JOURNAL HOMEPAGE

Full Terms \& Conditions of access and use can be found at http://hrmars.com/index.php/pages/detail/publication-ethics 


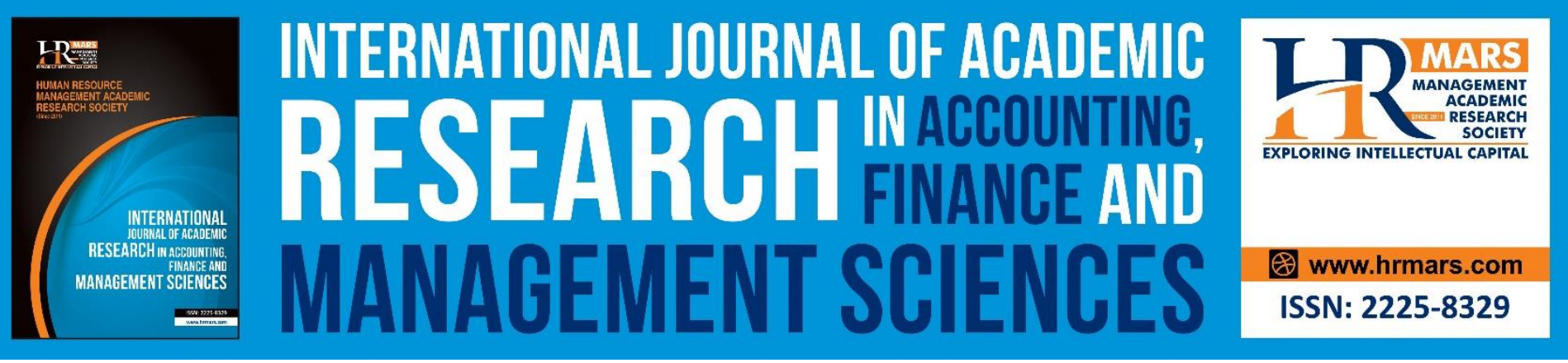

\title{
The Effect of IFRS Adoption on Corporate Performance of Listed Firms in Nigeria
}

\author{
Christopher Ifeanyichukwu Nwufo ${ }^{1}$, Mmanuel Ib Chima $^{2}$ \\ ${ }^{1}$ Department of Accounting, Faculty of Management Sciences, University of Abuja, Nigeria, \\ ${ }^{2}$ Accounts and Audit Department, STARBIZ Lynk Ventures Ltd, Abuja, Nigeria \\ 2Email: bestnuel2007@yahoo.com
}

\begin{abstract}
International Financial Reporting Standards (IFRS) are standards and framework adopted globally to harmonize divergent national standards and improve financial reporting quality. This study empirically investigated the effect of IFRS adoption on the performance of listed firms in Nigeria using data from all the 21 banks listed on the Nigerian Stock Exchange as at $31^{\text {st }}$ December 2016 . Using two robust performance measures - profitability and growth, a multiple regression model was used to test the hypothesis of this study. The research also carried out a pre and post study to investigate if there is any significant difference in the growth of listed banks in Nigeria following the adoption of IFRS. The study reveals that the adoption of IFRS has no significant effect on performance vis - a vis the profitability and growth of listed banks in Nigeria. Findings from this study also reveals that IFRS adoption has no significant effect on the Pre and Post growth of listed banks in Nigeria.
\end{abstract}

Keywords: International Financial Reporting Standards, Corporate Performance, Profitability, Growth.

\section{Introduction}

\section{Background of the Study}

International Financial Reporting Standards (IFRS) is the blueprint, pivot and cornerstone for the preparation and presentation of financial statements for corporate entities to ensure standardization, globalization and credibility of financial reports across international borders. Statements of Accounting Standards (SAS) were hitherto used as guide in the preparation and presentation of financial statements in Nigeria prior to the adoption of International Financial Reporting Standards (IFRS) in 2012. Thus IFRS represents a benchmark for the preparation and presentation of financial statements for business entities in Nigeria post 2011.

IFRS which are issued by the International Accounting Standards Board (IASB) ensures standardization and globalization of financial statements by corporate bodies. Osisioma (2012) surmises that accounting profession was terribly rocked by a series of professional misadventures that tore at the heart of the discipline with financial scandal in Enron, Worlddown, Global Crossing, 
INTERNATIONAL JOURNAL OF ACADEMIC RESEARCH IN ACCOUNTING, FINANCE AND MANAGEMENT SCIENCES

Vol. 11, No. 3, 2021, E-ISSN: 2225-8329 ๑ 2021 HRMARS

Xerox, Deutsche, Telekon, Qwest, Waste management, Viuendi, Centrica, Royal Dutch/Shell and Tyco all through the United States, Europe, Asia and the Caribbean while in Nigeria we had African Petroleum, Cadbury among others. Nobes (2011) affirms that international differences in financial reporting create problems because many users such as investment analysts acting for investors in equity or debt assess companies internationally on a comparative basis.

According to Salaudeen et al (2015), one of the prevailing issues among corporate entities is how to build investors' confidence in the economy through ethical accounting standards to enhance financial reporting transparency. The objectives and importance of IFRS as highlighted by Fowokan (2011) amongst others includes; to work actively with the national standard setters to bring about convergence of national accounting standards as well as to help participants (investors, stock brokers inclusive) in various markets across the globe to understand financial statements of Multinational corporations.

Due to differences in cultural, legal, political and other factors among nations there has been differences in regulatory standards and difficulty in assessing the performance of multinational corporations, thereby creating a need to harmonize and converge reports into an acceptable single set of standards. Herbert et al (2013) assert that the fast pace of globalization with integration of national financial markets has stimulated the need for a common financial language, otherwise called IFRS because good financial reporting makes investment and financial decisions more efficient. To ensure that such reports meet the needs and requirements of both national and international financial users, several standards and regulations have evolved overtime. Hence financial reporting has become the fundamental base upon which investors and other users rely on to make investment decisions and to evaluate corporate performance.

Nigeria has not been left out of the global moves towards this single set of worldwide regulations and standards. Consequently, the Nigeria Federal Executive Council had on 28 July, 2010, approved $1^{\text {st }}$ January, 2012 as the effective date for convergence of accounting standards in Nigeria with IFRS; and on $3^{\text {rd }}$ September, 2010, the NASB now referred to as FRC announced a staged implementation of IFRS with the expectation that all publicly quoted entities are to implement IFRS commencing from January 2012 and ending January 2014. The adoption of IFRS - a guideline created by IASB, is intended to strengthen the financial reporting frameworks of firms in Nigeria. Financial Reporting Council of Nigeria was empowered to regulate standards in Nigeria under Financial Reporting Council Act of 2011.

The international Financial Reporting Standards (IFRS) are standards and frameworks adopted by the International Accounting Standards Board (IASB) with a view towards the convergence, harmonization and internationalization of financial reporting globally. Invariably, IFRS is seen as an international GAAP and standards set to assist those involved in the preparation of financial statements all over the world to prepare and present financial reports that are seen to be of high quality, transparent and comparable internationally by both national and multi - national investors. In Europe and around the world, the adoption of International Financial Reporting Standards represents the most important change in accounting regulation in recent years.

In Nigeria, the banking industry is believed to be one of the leading sectors capable of propelling economic development of the nation. It provides funds for capital market participants and promotes investment. Prior to the mandatory adoption of IFRS by banks in Nigeria, the Companies and Allied Matters Act (CAMA, 1990) as amended till date, Banks and Other Financial Institution Act (BOFIA, 1999) as amended, Central Bank of Nigeria Act (CBN Act, 1999), Nigerian Security and Exchange 
INTERNATIONAL JOURNAL OF ACADEMIC RESEARCH IN ACCOUNTING, FINANCE AND

MANAGEMENT SCIENCES

Vol. 11, No. 3, 2021, E-ISSN: 2225-8329 @ 2021 HRMARS

Commission Act of 2003 as well local and international standards including professional pronouncements must be complied with by banks in the preparation and presentation of their financial reports. For instance, Part 1, Schedule 2 of CAMA 1990 outlines the form and content of published corporate financial reports. Nowadays, all banks financial reports must be presented and published in conformity with the requirements of IFRS.

Following the adoption of IFRS in Nigeria, all commercial banks listed on the Nigeria Stock Exchange were mandatorily required to prepare and present their financial reports under IFRS by January, 2012. Since then, there were high expectations that this adoption will improve the quality of financial reporting, improve corporate performance of banks, attract more investors and improve the reporting framework in Nigeria.

Although there are studies conducted in Nigeria on the mandatory adoption of IFRS in Nigeria, very few studies actually researched on the effect of such adoption on the performance of the banking sector. Hence with few years after its adoption and due to dynamic nature of IFRS, this research study uses robust performance indicators to investigate the effect of IFRS adoption on the performance of banks listed on the Nigeria Stock Exchange (NSE).

\section{Statement of Problem}

IFRS effects vary from country to country, period to period and firm to firm. ICAEW (2014) asserts that on many issues that arise from the EU'S adoption of IFRS, the evidence is unclear and different researchers arrive at different answers. This is usually because they have applied different tests or looked at different samples or at different periods. Several studies have been carried out to examine the extent to which IFRS improve financial reporting quality and provides additional information to users. Multinational investors want financial statements and reports that are comparable with those in other parts of the world for making strategic decision. As such, many foreign investors will require their subsidiaries in Nigeria not to present their reports in local standards but to report in accordance with IFRS so that the parent company can comply with the reporting requirements in its domain territory. It is expected that following IFRS adoption by the Nigerian Banks, the complications of the subsidiaries having to prepare different sets of records for reporting locally and internationally will be reduced, thereby facilitating business compliance globally. Before the global convergence to International Financial Reporting Standards (IFRS), different countries of the world have had their respective accounting standards, developed, issued and regulated by their respective local bodies. Damagum \& Chima (2014) highlighted that corporate regulators in different countries usually adopts the use of specifically designed codes to facilitate regulations. In Nigeria for instance, the Nigerian Accounting Standards Board (NASB) was responsible for developing, issuing and regulating accounting standards since 1982 till July 20th, 2011 when the Financial Reporting Council Bill was signed into law.

Indiael (2015) reveals that the existing empirical crams and conclusions on the impact of IFRS on corporate entities are mixed. This indicates the pressing need for empirically tested studies of this nature that are country and period specific. Saidu \& Umar (2014) highlight that " in the wake of financial crises in the late 1990s, the international community emphasized on the major role that the observance of international standards and codes of best practices can play in strengthening national and international financial systems.

Several empirical literatures emerged that offers contradictory findings about the question to what extent accounting standards contribute to the decision usefulness of financial reporting information. 
Prior researches also have produced inconsistent and mixed findings and consequent upon the gap in literature arising from the conflicting views on the impact of IFRS adoption on financial reports in Europe, Asia and other regions, this study thus provides evidence from the Nigeria perspective by studying the effect of such mandatory adoption on the performance of listed banks in Nigeria.

ICAEW (2014) find increased liquidity following mandatory IFRS adoption for firms in France and Germany, but report mixed findings for UK and Swedish firms. IFRS is constantly changing; therefore the effects found by one research will not always continue to apply indefinitely. Effects of IFRS vary from firm to firm and country to country hence the impetus for this study on listed banks and evidence from Nigeria. Also the industry specific nature of IFRS made this research imperative for Nigerian banks. Therefore this study ascertained the effect of IFRS adoption on performance of listed commercial banks in Nigeria.

\section{Objectives of the Study}

The main objective of this study is to empirically ascertain the effect of IFRS adoption on the performance of listed banks on Nigerian Stock Exchange (NSE).

Other specific objectives are;

i. To evaluate the effect of IFRS adoption on banks profitability.

ii. To evaluate the effect of IFRS adoption on banks growth.

iii. To ascertain the difference in the pre and post IFRS adoption on growth of listed banks.

\section{Research Questions}

Based on the objective of the study, the following research questions are pertinent;

i. To what extent does IFRS adoption affect the profitability of listed banks in Nigeria?

ii. To what extent does IFRS adoption affect the growth of listed banks in Nigeria?

iii. Does difference exist between the pre and post IFRS adoption on growth of listed banks?

\section{Research Hypotheses}

To lend empirical credence to this study, the following research hypotheses are formulated;

$\mathrm{Ho}_{1}$ : There is no significant effect of IFRS adoption on the profitability of listed banks in Nigeria.

$\mathrm{Ho}_{2}$ : There is no significant effect of IFRS adoption on the growth of listed banks in Nigeria.

Ho3: There is no significant difference between the pre and post IFRS adoption on growth of listed banks in Nigeria.

\section{Significance of the Study}

Following the harmonization and convergence of accounting standards globally and the adoption of IFRS in Nigeria especially by the banking sector in the year 2012, the benefits accruing from this study are enormous and significant as it will help capital market participants to understand the relevance of IFRS in improving corporate growth through earnings management. It will also provide a framework for Financial Reporting Council of Nigeria and Central Bank of Nigeria to effectively understand how IFRS adoption has affected the activities of the banking sector through the findings and recommendation. 
INTERNATIONAL JOURNAL OF ACADEMIC RESEARCH IN ACCOUNTING, FINANCE AND

MANAGEMENT SCIENCES

Vol. 11, No. 3, 2021, E-ISSN: 2225-8329 @ 2021 HRMARS

\section{Scope of the Study}

The scope of this study is limited to the banking sector especially the commercial banks listed on the Nigerian Stock Exchange. It is limited only to the effect of IFRS on listed commercial Banks performance using two variables to measure such effect. The period of coverage is ten (10) years (2007 -2016), thus cutting across the 5 years before adoption $(2007-2011)$ and 5 years post IFRS adoption era (2012 - 2016).

\section{Overview of Bank's Performance in Nigeria}

The banking sector plays a vital role in the economic growth and development of a nation. Ismail (2010) surmise that Banks in Nigeria are characterized by high competition, huge deposits and varied investment opportunities. As a result of the consolidation of the banking system completed in 2005, Nigeria witnessed growth in the banking sector. Banks expanded very rapidly, raising large amounts of new capital and attracting large volumes of new deposits. These were in turn deployed to fund enormous growth in the bank loan portfolio. Nzotta (2014) surmise that banking sector is the dominant sector in the Nigerian financial service industry and the most vibrant component because whatever difficulties it passes through affects the entire economy greatly. Nwala \& Adebayo (2016) asserts that post consolidation era contributes immensely to the growth of Nigerian banks. Yahaya, Yusuf \& Dania (2015) surmise that growth is natural logarithm of gross earnings of bank $i$ at year $t$ and summarized that under IFRS, important financial performance figure, such as profitability and growth, appear to be higher.

\section{Theoretical Framework}

The relevant theoretical theories related to this study are:

\section{(a) Stakeholders Theory}

This study adopts the stakeholders' theory as the fundamental theory upon which this research is anchored on. Ian Mitroff propounded the stakeholders' theory in 1983 and sees a stakeholder as a person or group that can affect or be affected by how an entity conducts its operations. The stakeholder theory looks at the relationship between an organization and others in the environment. In other words, it looks at the interaction of internal and external factors and its influence on the conduct of corporate activities. The principal reason behind the stakeholder's theory is that organizations can survive longer and perform better when they manage their stakeholder relationship effectively. The stakeholder's theory offers a model which is an instrumental framework for investigating the relationship between firm performance and the practice of management. In relation to regulatory standards, the stakeholder's theory is seen as a conceptual framework for good business ethics as it addresses moral and ethical values in the management of an organization.

Donaldson \& Preston (1995); Clarkson (1994) defines stakeholders as persons, or entities who either voluntarily or involuntarily becomes exposed to risk from the activities of a firm. John \& Corporate firms are often bound by their obligations to its stakeholders and this usually helps them create new moral obligations. This study is investigating empirically the impact of IFRS adoption on corporate performance and stakeholder's theory is a relevant anchor for this study as it suggests that the purpose of a business is to perform very well and create more values for its stakeholders. Hence this theory really explains one of the motives for firms IFRS adoption globally in their financial statements. 
INTERNATIONAL JOURNAL OF ACADEMIC RESEARCH IN ACCOUNTING, FINANCE AND

MANAGEMENT SCIENCES

Vol. 11, No. 3, 2021, E-ISSN: 2225-8329 ๔ 2021 HRMARS

\section{Empirical Review}

There are lots of growing numbers of researches carried out about the IFRS adoption. Covrig, Defond \& Hung (2007) documented that foreign mutual fund ownership is significantly higher for IFRS adopters compared to local GAAP firms and that the difference in mutual fund holdings increases for firms in poor information environments and with low visibility, suggesting that IFRS reporting can help firms attract foreign institutional investment. Hung \& Subramanyam (2007) investigated the effect of IFRS adoption on the financial statement and their value relevance for a sample of German listed firms during 1998-2002. By implementing an innovative research design they compared accounting numbers reported under German accounting rules with those under IAS for the same set of firm years and document how IAS adoption changes key financial measures and the value relevance of financial statement information. They reported that the total assets and book values of equity as well as variability of book value and net income are significantly higher under IAS/IFRS than under German GAAP.

Ibiamike \& Briggs (2014) evaluate the impact of IFRSs adoption by Nigerian listed firms using key financial ratios used by investors. The study used an innovative design known as "same firm year" research design to examine how IFRS adoption changes key financial ratios of Nigeria listed firms. Their findings reveal that IFRS adoption has caused a negative impact on the financial ratios of Nigerian listed firms but the impact was not statistically significant.

Yahaya et al (2015) investigated the effect of IFRS on earning management behavior of listed Deposit Money Banks in Nigeria. The study examines how the change in the recognition and measurement of banks loan loss provision affects management behavior. Using a sample of 15 deposit money banks listed on the Nigeria Stock Exchange (NSE), financial data in respect of the periods before and after adoption of FIRS (I e 2005 to 2008 and 2009 to 2013) were selected. Their study reveals that the restriction to incurred loss under IFRS significantly reduced the ability of banks to engage in earning management. Indiael (2015) evaluated the impact of IFRS on earning management: A review of empirical evidence. The findings reveal that the existing empirical crams and conclusions thereon are mixed.

\section{Summary of Empirical Review}

Kamal \& Bhuiyan (2013); Iyaha \& Faboyede (2011); Cai \& Wong (2010); Okpara (2012); Azobu (2010); Chukwu \& Okoye (2016); Odia (2015); Nobes (2011); Okoye \& Ezejiofor (2014) are of the view that IFRS despite being country specific is beneficial for financial reporting. Nobes (2011) reiterated that there are major, deep-seated and long lasting differences between countries. These include culture, legal systems, tax systems, financial systems and language. Therefore, international differences in financial reporting are expected, inevitable and welcome. Chukwu \& Okoye (2016) affirm that the International Financial Reporting Standard (IFRS), issued by the International Accounting Standard Board (IASB) is increasingly becoming the preferred accounting regime among companies. Indiael (2015) reveals that the existing empirical arms and conclusions on the impact of IFRS on corporate entities are mixed. This indicates the pressing need for empirically tested studies of this nature that are country specific. Also Soderstrom \& Sun (2007) emphasize that the mixed findings can be partly explained by the influence of country specific factors.

Few researchers have been carried on effect of IFRS on banks in Nigeria, but IFRS is constantly changing, as such the effect found by one research will not always continue to apply indefinitely. Therefore, this research filled this gap by ascertaining the effect of IFRS on growth of listed 
INTERNATIONAL JOURNAL OF ACADEMIC RESEARCH IN ACCOUNTING, FINANCE AND

MANAGEMENT SCIENCES

Vol. 11, No. 3, 2021, E-ISSN: 2225-8329 @ 2021 HRMARS

commercial banks in Nigeria. Also, since the adoption of IFRS in developing countries like Nigeria especially by banks in Nigeria, studies in literature has been few particularly studies on IFRS adoption and its effect on growth, this research work will add to the growing knowledge on IFRS and corporate growth of listed banks in Nigeria. Finally, this research work is anchored on the stakeholders theory because, it recognizes all users of accounting information such as debtors, creditors, financial analyst, government, the public, employers and employees.

\section{Research Design}

This research work used descriptive statistics of annual reports of listed banks to empirically investigate the effect of International Financial Reporting Standards on banks performance.

\section{Sources and Methods of Data Collection}

For the purpose of this study only secondary sources of data were used, these consist of the Annual Reports of listed banks as well as Fact Books from the Nigeria Stock Exchange (NSE). Also annual reports from the Securities and Exchange Commission (SEC), Nigeria Deposit Insurance Corporation (NDIC) and Central Bank of Nigeria (CBN) were used. Financial data in respect of the penultimate period before IFRS adoption were used as well as data from post IFRS adoption. Hence this study covers annual reports of listed banks from year $2007-2016$.

The year 2007 - 2011are used to investigate the pre IFRS adoption era while the year 2012 - 2016 are used to study the post IFRS adoption era.

\section{Population of the Study}

The population of this study comprises twenty one (21) Commercial Banks listed on the Nigerian Stock Exchange as at $31^{\text {st }}$ December, 2016 as shown on appendix

\section{Sampling Technique and Sample Size}

For the purpose of this research, stratified sample technique was used in selecting sample size of fifteen (15) listed commercial banks in Nigeria. This is very justified and equitable since all the banks were listed before the adoption of IFRS in 2012. Hence, the sample consist of the fifteen (15) banks for a period of ten years (2007 to 2016). This period is further sub analyzed into pre IFRS adoption era -2007 to 2011 and post IFRS adoption era - 2012 to 2016.

\section{Validity of the Technique Used}

Validity is very important in research as it certify the integrity of conclusions that are generated from a piece of research. The validity of any research instrument is being able to measure what it is supposed to measure. We believe that this research study is validated by the fact that all the data used were extracted from audited company's annual reports which have high degree of credibility as well as from the Fact Books from the Nigeria Stock Exchange (NSE).

\section{Variable Specification}

\section{Dependent and Independent Variables}

The dependent variable of this study is International Financial Reporting Standards (IFRS) which is measured by a dummy variable representing the regulatory regime, 1 for financial reports under IFRS and 0 for financial reports under NGAAP. 
INTERNATIONAL JOURNAL OF ACADEMIC RESEARCH IN ACCOUNTING, FINANCE AND

MANAGEMENT SCIENCES

Vol. 11, No. 3, 2021, E-ISSN: 2225-8329 @ 2021 HRMARS

The independent variables are two performance indicators / measures comprising Profitability and Growth.

\section{Model Specification}

The multiple linear Regression equation empirical model was used for this study. The regression model shown in the equation below is estimated using pooled (panel) data (pre-adoption, 2007-2011) and (post-adoption, 2012-2016) and fitted with various measures of financials as defined in the equation below. The empirical analysis used the binary logistic regression analysis. The logistic regression analysis is useful in analyzing categorical data, where the dependent variable is dichotomous and takes only two values, i.e. 0 and 1.

The multiple regression equation is given as:

$I F R S=\beta 0+\beta 1 P f r t y+\beta 2 \ln (g . e r)+\beta 3 S I Z+\beta 4 \ln ($ age $)+\mathrm{e}_{i t}$

These proxies are explained below:

Dependent Variable

IFRS = INTERNATIONAL FINANCIAL REPORTING STANDARDS. FRSs is a dummy variable representing the regulatory regime, 1 for financial reports under IFRS and 0 for financial reports under NGAAP.

Independent Variables

The independent variables are:

Profitability and Growth, used as proxies for Banks Performance, while Firm Size and Age are proxies used for control variables. They are computed using the following variables:

1. Pfty = Profitability variable which is measured using the following proxies:

(i) NIM which is Net Operating Income Margin of bank i at year $t$

(ii) EPS which is Actual Earnings per Share of bank $i$ at year $t$

2. In(g.er)Growth = Increase in gross earnings measured by Total income before taxes and deductions or the total revenues minus expenses

.3. Size = FIRM SIZE representing firm growth (measured by the natural logarithm of total assets of the company at year end).

4. Age $=16-$ year of establishment of Bank.

5. $\beta_{\mathrm{o}}=$ intercept coefficient

$(\beta i=1, \ldots \ldots ., 4)=$ coefficient of each of the independent variables and control variables.

6. $\mathrm{e}=$ error estimate.

7. $\ln =$ Natural log

\section{Techniques and Statistical Tools for Data Analysis}

The techniques adopted for the data presentation and analysis include tables with summary and descriptive statistics. Preliminary data set test such as the Multicollinearity test using the variance inflation factors (VIF) was computed. Also, a binary logistic multiple Regression model was used to ascertain the effect of IFRSs on corporate performance variables. The co-efficient of determination (Cox \& Snell $R^{2}$ ) as well as the Nagelkerke adjusted $R^{2}$ were computed to determine the proportion of explained variation in the dependent variables. The Descriptive Statistics showing the mean, standard deviation, minimum and maximum values were also computed. Finally a mean comparison 
INTERNATIONAL JOURNAL OF ACADEMIC RESEARCH IN ACCOUNTING, FINANCE AND

MANAGEMENT SCIENCES

Vol. 11, No. 3, 2021, E-ISSN: 2225-8329 @ 2021 HRMARS

test of the pre and post IFRS adoption was tested by Mann-Whitney test statistics at $5 \%$ level of significance.

Decision rule -

(a) Reject the null hypothesis (Ho) if $p$ value is $<.05$ significant level.

(b) Accept the null hypothesis $(\mathrm{Ho})$ of $\mathrm{p}$ value is $>.05$ significant level.

\section{Data Presentation}

The descriptive statistics are presented on Table 4.1

Table 4.1 Descriptive statistics

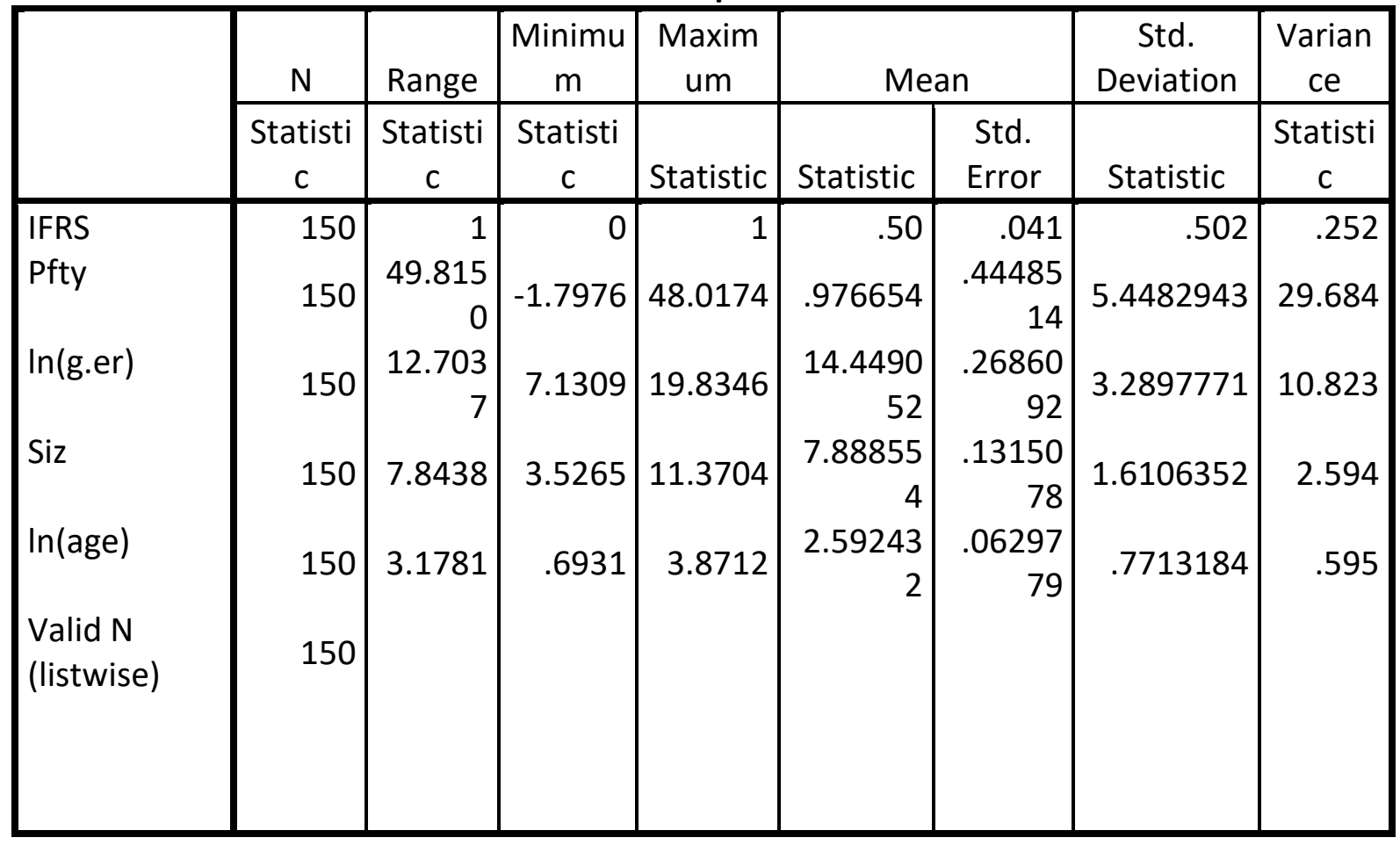

Source: SPSS Output

The table 4.1 is the statistics table that presents the properties of the data set. The mean of the profitability is 0.9766 with standard deviation of 5.4482 . This means that the profit can deviate from mean to both sides by 5.4482. The mean of the Growth is 14.4490 with standard deviation of 3.2897. This means that the Growth can deviate from mean to both sides by 3.2897 . 
INTERNATIONAL JOURNAL OF ACADEMIC RESEARCH IN ACCOUNTING, FINANCE AND MANAGEMENT SCIENCES

Vol. 11, No. 3, 2021, E-ISSN: 2225-8329 @ 2021 HRMARS

Table 4.2 Group Statistics

\begin{tabular}{|l|l|r|r|r|r|}
\hline & IFRS & $\mathrm{N}$ & \multicolumn{1}{c|}{ Mean } & $\begin{array}{c}\text { Std. } \\
\text { Deviation }\end{array}$ & $\begin{array}{c}\text { Std. Error } \\
\text { Mean }\end{array}$ \\
\hline Pfty & 0 & 75 & .967100 & 5.5798366 & .6443040 \\
& 1 & 75 & .986209 & 5.3510927 & .6178910 \\
\hline $\ln$ (g.er) & 0 & 75 & 14.472269 & 2.9789892 & .3439840 \\
& 1 & 75 & 14.425835 & 3.5938906 & .4149867 \\
\hline Siz & 0 & 75 & 7.516954 & 1.6351506 & .1888109 \\
& 1 & 75 & 8.260154 & 1.5065607 & .1739626 \\
\hline $\ln$ (age) & 0 & 75 & 2.367492 & .8915725 & .1029499 \\
& 1 & 75 & 2.817372 & .5481229 & .0632918 \\
\hline
\end{tabular}

\section{Source: SPSS Output}

Table 4.2 above presents the group statistics determining variables on the effect IFRS pre and post. Making IFRS a dummy variable with indicators of 0 for pre IFRS and 1 for post IFRS. The determining variables with their respective mean difference is as follows: for Pfty an Increased mean is observed between the pre IFRS and the post IFRS; for In(g.er) a decreased mean is observed between the pre IFRS and the post IFRS; for I; for size an Increased mean is observed between the pre IFRS and the post IFRS while for In(age) an Increased mean is observed between the pre IFRS and the post IFRS.

Table 4.3 Multicollinearity test

\begin{tabular}{|c|c|c|c|}
\hline & & \multicolumn{2}{|c|}{ Collinearity Statistics } \\
\hline \multicolumn{2}{|c|}{ Model } & Tolerance & VIF \\
\hline \multirow[t]{4}{*}{1} & Pfty & .043 & 1.874 \\
\hline & In(g.er) & .811 & 1.234 \\
\hline & Siz & .767 & 1.304 \\
\hline & In(age) & .866 & 1.155 \\
\hline
\end{tabular}


INTERNATIONAL JOURNAL OF ACADEMIC RESEARCH IN ACCOUNTING, FINANCE AND MANAGEMENT SCIENCES

Vol. 11, No. 3, 2021, E-ISSN: 2225-8329 @ 2021 HRMARS

Tabe 4.4 Variance inflation factors (VIF)

\begin{tabular}{cc}
\hline VIF & Status of predictors \\
\hline VIF $=1$ & Not correlated \\
$1<$ VIF $<5$ & Moderately correlated \\
VIF $>5$ to 10 & Highly correlated
\end{tabular}

As observed on Table 4.3, the VIF coefficient was obtained and observed to range from 1.874 to 1.136 for all the variables. Which falls within the range $1<\mathrm{VIF}<5$ that implies that there is a presence of moderately correlated explanatory variables in the models formulated,

Table 4.5.1 Mann-Whitney Test

\begin{tabular}{|l|l|r|r|r|}
\hline \multicolumn{1}{|c|}{} & Ranks \\
\hline Pfty & IFRS & $\mathrm{N}$ & $\begin{array}{c}\text { Mean } \\
\text { Rank }\end{array}$ & Sum of Ranks \\
& 0 & 75 & 78.41 & 5881.00 \\
& 1 & 75 & 72.59 & 5444.00 \\
& Total & 150 & & 5416.50 \\
\hline In(g.er) & 0 & 75 & 72.22 & 5908.50 \\
& 1 & 75 & 78.78 & 4639.00 \\
& Total & 150 & & 6686.00 \\
\hline Siz & 0 & 75 & 61.85 & 4768.50 \\
& 1 & 75 & 89.15 & 6556.50 \\
& Total & 150 & & \\
\hline In(age) & 0 & 75 & 63.58 & \\
& 1 & 75 & 87.42 & \\
& Total & 150 & & \\
& & & & \\
& & &
\end{tabular}

Table 4.5.2

\begin{tabular}{|c|c|c|c|}
\hline Pfty & In(g.er) & Siz & $\ln ($ age $)$ \\
\hline Mann-Whitney U & 2566.50 & 1789.00 & 1918.50 \\
\hline 2594.000 & 0 & 0 & 0 \\
\hline Wilcoxon W & 5416.50 & 4639.00 & 4768.50 \\
\hline 5444.000 & 0 & 0 & 0 \\
\hline Z & -.925 & -3.847 & -3.362 \\
\hline Asymp. Sig. (2-tailed) & .355 & .000 & .001 \\
\hline
\end{tabular}

a. Grouping Variable: IFRS

The table 4.5 above presents the results for Mann-Whitney test for all the IFRS impact indicator variables for both the pre IFRS and the post IFRS period. The variable Pfty of the 15 deposit banks before the IFRS was compared to the post IFRS using the Mann-Whitney test with a p-value of 0.411 which is greater than the $0.05(5 \%)$ level of significance. This suggest that there is no significant 
INTERNATIONAL JOURNAL OF ACADEMIC RESEARCH IN ACCOUNTING, FINANCE AND MANAGEMENT SCIENCES

Vol. 11, No. 3, 2021, E-ISSN: 2225-8329 @ 2021 HRMARS

difference between the pre and post IFRS in terms of the banks Pfty. However for the variable In(g.er) of the listed banks before the IFRS was compared to the post IFRS using the Mann-Whitney test with a p-value of 0.355 which is greater than the $0.05(5 \%)$ level of significance. This suggest that there is no significant difference between the pre and post IFRS in terms of the banks In(g.er).

Table 4.6 Logistic Regression

\begin{tabular}{|c|c|c|c|c|c|c|c|c|c|}
\hline & \multirow[b]{2}{*}{ B } & \multirow[b]{2}{*}{ S.E. } & \multirow[b]{2}{*}{ Wald } & \multirow[b]{2}{*}{ Df } & \multirow[b]{2}{*}{ Sig. } & \multirow[b]{2}{*}{$\operatorname{Exp}(B)$} & \multicolumn{2}{|c|}{$\begin{array}{c}\text { 95\% C.I.for } \\
\operatorname{EXP}(B)\end{array}$} \\
\hline & & & & & & & & Lower & Upper \\
\hline \multirow{8}{*}{$\begin{array}{l}\text { Step } \\
1^{a}\end{array}$} & Pfty & -.001 & .032 & .001 & 1 & .975 & .999 & .938 & 1.064 \\
\hline & Inger & -.099 & .064 & 2.406 & 1 & .121 & .906 & .799 & 1.027 \\
\hline & Siz & .332 & .133 & 6.182 & 1 & .013 & 1.394 & 1.073 & 1.810 \\
\hline & Inage & .993 & .285 & 12.193 & 1 & .000 & 2.701 & 1.546 & 4.717 \\
\hline & Constant & - & 1.456 & 11.355 & 1 & .001 & .007 & & \\
\hline & & & & & & & & & \\
\hline & & & & & & & & & \\
\hline & & & & & & & & & \\
\hline
\end{tabular}

a. Variable(s) entered on step 1: Pfty, Inger, siz, Inage.

Table 4.6 shows the deposit money banks performance variables. When regressed on IFRS $(0=$ preIFRS, 1 = postIFRS) variable have returned the following as results. The multiple logistic regression analysis finding indicates that size and age had significantly been influenced by IFRS whereas Pfty, (g.er) did not at alpha $=0.05(5 \%)$.

Table 4.7: Model Summary of the Relationship between IFRS and the Listed Bank Performance Variable

\begin{tabular}{|l|c|c|c|}
\hline Step & $\begin{array}{c}-2 \text { Log } \\
\text { likelihood }\end{array}$ & $\begin{array}{c}\text { Cox \& Snell R } \\
\text { Square }\end{array}$ & $\begin{array}{c}\text { Nagelkerke R } \\
\text { Square }\end{array}$ \\
\hline 1 & $181.206^{\mathrm{a}}$ & .163 & .218 \\
\hline
\end{tabular}

Further evaluation of Table 4.7 (Model Summary section) shows that the (Cox \& Snell R Square) $\mathrm{R}^{2}$ value of 0.163 which infers that about $16.3 \%$ of the observed variability in the Bank performance variables is explained by the IFRS variable.

Regression model equation is as follows:

IFRS $=-4.906-0.001$ Pfrty $-0.099 \ln ($ g.er $)+0.332 S I Z+0.993($ age $)$

\subsection{Test of Hypotheses}


INTERNATIONAL JOURNAL OF ACADEMIC RESEARCH IN ACCOUNTING, FINANCE AND

MANAGEMENT SCIENCES

Vol. 11, No. 3, 2021, E-ISSN: 2225-8329 @ 2021 HRMARS

The following hypotheses formulated are hereby subjected to statistical test:

Test of Hypothesis 1

$\mathrm{Ho}_{1}$ : There is no significant effect of IFRS adoption on the profitability of listed banks in Nigeria.

Table 4.8 Test of Hypothesis 1

\begin{tabular}{lll|llll}
\hline & B & SE & Wald & Df & Sig. & Exp(B) \\
Profitability & -0.001 & 0.032 & 0.001 & 1 & 0.975 & 0.999 \\
\hline
\end{tabular}

Source: Extract from Table 4.6

Test of Hypothesis 2

$\mathrm{Ho}_{2}$ : There is no significant effect of IFRS adoption on the growth of listed banks in Nigeria.

Table 4.9 Test of Hypothesis 2

\begin{tabular}{lll|llll}
\hline & B & SE & Wald & Df & Sig. & Exp(B) \\
In (g.er) Growth & -0.099 & 0.64 & 2.406 & 1 & 0.121 & 0.906 \\
\hline
\end{tabular}

\section{Source: Extract from Table 4.6}

On table 4.9 since P-value 0.906 is greater than 0.05 level of significance, thus hypothesis 1 is accepted. Therefore IFRS has no significant effect on growth of Banks in Nigeria.

Test of Hypothesis 3

$\mathrm{Ho}_{2}$ : There is no significant difference between pre and post IFRS adoption on growth of listed Banks in Nigeria.

Table 4.10 Test of Hypothesis 3

\begin{tabular}{|l|r|}
\hline & \multicolumn{1}{|c|}{$\ln$ (g.er) } \\
\hline Mann-Whitney U & 2566.500 \\
Wilcoxon W & 5416.500 \\
Z & -.925 \\
Asymp. Sig. (2-tailed) & .355 \\
\hline
\end{tabular}

On table $4.10 p$-value 0.355 is greater than 0.05 (5\%) level of significance. Therefore the null hypothesis is accepted, thus there is no significant difference between pre and post IFRS adoption on growth of listed banks in Nigeria.

\section{Discussion of Findings}

The analysis result indicates that Pfty, which yielded a Beta $(\beta)$ of -.001 , was deemed to not be statistically significant since the obtained $p$-value is greater than 0.05 level of significance. Therefore, IFRS adoption has no significant effect on Pfty level of the Nigeria's listed banks. Therefore the hypothesis that IFRS adoption has no significant effect on profitability is accepted. This agrees with the findings of Latridis (2010); Yahaya, Yusuf \& Dania (2015); Street \& Gray (2000). This is also against the findings of Lantto \& Sahlstrom (2009).

Furthermore, the result shows that growth, which yielded a Beta $(\beta)$ of -.099 , and a $p$-value of 0.121 , were deemed to be not statistically significant since the obtained p-value $(0.121)$ which is greater than 0.05 level of significance. Therefore thus, IFRS adoption has no significant effect the growth level of the Nigeria's listed banks. Therefore the hypothesis that IFRS adoption has no significant effect on 
the growth is accepted. This agrees with the findings Yahaya, Yusuf \& Dania (2015); Blanchette (2011) ; Chukwu \& Okoye (2016); Contrary to Latridis (2010).

The result also shows that the profitability which depicts a p-value of 0.411 is greater than .05 level of significant. Thus there is no significant difference in the pre and post adoption on profitability of listed banks in Nigeria. This agrees with the findings of Latridis (2010); Yahaya, Yusuf \& Dania (2015); Street \& Gray (2002). This is also against the findings of Lantto \& Sahlstrom (2009). Also finding shows that growth gives a p-value of 0.355 which is greater than 0.05 level of significant. Therefore, there is no significant difference in the pre and post adoption on growth of listed banks in Nigeria. This agrees with the findings Yahaya, Yusuf \& Dania (2015); Blanchette (2011); Chukwu \& Okoye (2016); Contrary to Latridis (2010). This implication of the study is that the increase in mean of profits and decrease in mean of growth are not attributable to adoption of IFRS.

\section{Summary of Findings}

Following the data analyses and interpretation of results, the summary of findings are as follows:

(b) IFRS adoption has no significant effect on growth of listed banks in Nigeria.

(d) IFRS adoption has no significant difference on pre and post growth of listed banks in Nigeria.

\section{Conclusion}

Our findings indicate that International Financial Reporting Standards have no significant effect on listed banks as evaluated using profitability and growth, and there is no significant difference between pre and post adoption on the performance of listed bank in Nigeria.

\section{Recommendations}

Following the elucidation of this study, findings and conclusion the following recommendations are hereby suggested:

(a) The Financial Reporting Council of Nigeria should sponsor continuous researches on the application of IFRS in Nigeria.

(b) The Financial Reporting Council should undertake aggressive publicity on the IFRS operation in Nigeria.

(c) Central Bank of Nigeria, Financial Reporting Council of Nigeria, Nigeria Deposit Insurance Corporation and Securities and Exchange Commission should continuously monitor IFRS compliance by Banks.

(d) There should be massive educational training and re-training on IFRS for students, employees, employers, accountants and auditors.

\section{References}

Abata, M. A. (2015). Impact of IFRS on Financial Reporting Practices in Nigeria, A Case of (KPMG) Global Journal of Contemporary Research in Accounting, Auditing and Business Ethics 1 (1), $263-281$.

Asian, A. A., \& Dike A. (2015) IFRS Adoption and Accounting Quality, of Quoted Manufacturing Firms in Nigeria: A Cross Sectional Study of Brewery and Cement Manufacturing Firms. International Journal of Business and Management Review 3 (6) 61-77.

Azobu, M. (2010). Adoption of IFRS in developing countries. International Journal of Business and Management, 7(3), 155-157. 
INTERNATIONAL JOURNAL OF ACADEMIC RESEARCH IN ACCOUNTING, FINANCE AND

MANAGEMENT SCIENCES

Vol. 11, No. 3, 2021, E-ISSN: 2225-8329 @ 2021 HRMARS

Blanchette, M., Franchois, E. R., \& Girard, J. U. (2011). The effect of IFRS on financial ratios early evidence from Canada. Certified General Accountants Association of Canada.

Cai, F., \& Wong, H. (2010). The effects of IFRS adoption on global capital market integration. International Business and Economic Research Journal, 9(10), 25-34.

Chiha, H., Trabels, N. S., \& Hamza, S. E. (2013). The Effective of IFRS on Earnings Quality in an European Stock Market: Evidence from France. Retrieved from http://www.idjrb.com/article2124pdf.

Chinwuba, O., \& Killian, O. (2011) "Potential Effects of the Adoption and Implementation of IFRS in Nigeria", www.transcampus.org. Committee on Roadmap Report on the Adopting of (IFRS) in Nigeria.

Christopher, N. (2011). International Variations in IFRS Adoption and Practice. London: Certified Accountants Education Trust.

Chua, Y. L., Cheong, C. S., \& Gould, G. (2012). The impact of mandatory IFRS adoption of accounting quality: Evidence from Australia. Journal of International Accounting Research 11(1), 119146.

Chukwu, J. P., \& Okoye, E. I. (2016). Effect of International Financial Reporting Standards Adoption on Timely Loss Recognition: Evidence from Nigeria and South Africa. ICAN Journal of Accounting and Finance 1(1), 59-70.

Damagum Y. M., \& Chima, E. I. (2014). An empirical Analysis of Corporate Governance Codes. Accountability Vs Enterprise: Evidence from Nigeria. International Journal of Accounting and Finance 3(1), $16-28$.

Defond, M., Xuesong H., Mingyi, H., \& Sidi, Li (2011). The impact of mandatory IFRS adoption on foreign mutual fund ownership: The role of comparability. Journal of Accounting and Economic 51, $240-258$.

Donaldson, T., \& Preston, L. E. (1995) The Stakeholder theory of the corporation: Concepts, evidence and implications. Academy of Management Review, 20, 65-91.

Federal Republic of Nigeria. (2003). Nigerian Accounting Standards Board Act, 2003 Act No. 22.

Federal Republic of Nigeria. (2011). Financial Reporting Council Act 2011. Act No. 6, Federal Republic of Nigeria Official Gazette, No. 54 Vol. 58.

Fiechter, P. (2011). The effects of the fair value option under IAS 39 on the volatility of bank earnings', Journal of International Accounting Research, 10, 85-108.

Fowokan, T. (2012). IFRS Adoption in Nigeria Tax Implication CITN Seminar on IFRS Adoption in Nigeria.

Glautier, M., \& Underdown, B. (2001). Accounting Theory and Practice. London: FT - Prentice Hall $7^{\text {th }}$ ed.

Goodwin, J., \& Ahmed, K. (2006). The impact of International Reporting Standards: Does Size Matter? Managerial Auditing Journal 21 (5) $460-475$.

Herbert, E. W., Tsegba, H. I., Ohanele , A. C., \& Anyahara, I. O. (2013). Adoption of International Financial Reporting Standards (IFRS): Insights from Nigerian Academics and Practitioners, Research Journal of Finance and Accounting 4 (6), 121 - 135.

IASB. (2006). Preliminary views on an improved conceptual framework for financial reporting: The objective of financial reporting and qualitative characteristics of decision-useful financial reporting information, Discussion Paper, Retrieved from www.iasb.org. 
INTERNATIONAL JOURNAL OF ACADEMIC RESEARCH IN ACCOUNTING, FINANCE AND

MANAGEMENT SCIENCES

Vol. 11, No. 3, 2021, E-ISSN: 2225-8329 ๑ 2021 HRMARS

latridis, G., \& Rouvolis, S. (2010). The post-adoption effects of the implementation of international financial reporting standards in Greece. Journal of International Accounting, Auditing and Taxation, 19, 55-65.

Ibiamke, N. A., \& Ateboh-Briggs, P. B. (2014). Financial Ratios Effect of International Financial Reporting Standards (IFRS): Adoption in Nigeria. International Journal of Business and Management Invention 3 (3), $50-59$.

ICAEW. (2014). The Effects of Mandatory IFRS Adoption in the EU: A Review of Empirical Research; London: ICAEW.

Inchausti, B. G. (1997). The Influence of Company Characteristics and Accounting Regulation on Information Disclosed by Spanish Firms. The European Accounting Review, vol. 6.

Indiael, D. K. (2015). The Impact of International Financial Standards (IFRS) on Earnings Management: A Review of Empirical Evidence. Journal of Finance and Accounting, 3 (3), $57-65$.

Iyoha, F. O., \& Faboyede, S. O. (2011). Adopting International Financial Reporting Standards (IFRS) A Focus on Nigeria. International Journal of Research in Commerce and Management. 2(1), 35-40.

Josiah, M., Okoye, A. E., \& Adediran, O. S. (2013). Accounting standards in Nigeria, the Journey so far. Research Journal of Business Management and Accounting, 2, 1-10.

Kunle, O. A., Omoruyi, E. P., \& Hamed, A. B. (2011). Impact of International Reporting Standard on Insurance Management in Nigeria. Middle Eastern Finance and Economics. Euro Journals Publishing INC. 2, 128-142.

Lin, C., Hua, C., Lin, W., \& Lee, W. (2012). IFRS Adoption and Financial Reporting Quality: Taiwan Experience. International Journal of Academic Research in Accounting, Finance and Management Sciences 2(4), 285-294.

NASB. (2010). Report of the committee on road map to the adoption of IFRS.

Nwala, M. N., \& Adebayo, O. A. C. (2016). An Assessment of Pre and Post Consolidation Performance of Nigerian Banks. Journal of Global Accounting 4(1) 63-70.

Nzotta, S. M. (2014). Money, Banking and Finance: Theory and Practice Revised Edition. Owerri Hudson-Jude Nigeria Publisher.

Okoye, P. V. C., Okoye, J. F. N., \& Ezejiofor, R. A. (2014). Impact of the IFRS Adoption on Stock Market Movement in Nigeria Corporate Organization. International Journal of Academic Research in Business and Social Sciences 4 (9), $202-218$.

Okoye, V. C., \& Ezejiofor, R. (2014). The Effect of Adoption of IFRS on the Stock Performance: Implications on investor's expectations Research. Journal of Finance and Accounting .Vol.5, (4) 8-12.

Okpala, K. E. (2012). "Adoption of IFRS and financial statement effects: The perceived implications on FDI and Nigeria economy," Australian Journal of Business and Management Research, 2(5) 76-83, 2012.

Osisioma, B. C. (2012). Regulatory Development: Financial Reporting Council and IFAC requirements. A paper presented at the 2012 mandatory professional development of Association of National Accountants of Nigeria (ANAN).

Owusu-Ansah, S., \& Yeoh, J. (2005). The effect of legislation on corporate disclosure practices. ABACUS, 41 (1), 92 - 109. 
INTERNATIONAL JOURNAL OF ACADEMIC RESEARCH IN ACCOUNTING, FINANCE AND

MANAGEMENT SCIENCES

Vol. 11, No. 3, 2021, E-ISSN: 2225-8329 @ 2021 HRMARS

Salaudeen, Y. M., Ibikunle, J., \& Chima, E. I. (2015). Unethical Accounting Practice and Financial Reporting Quality: Evidence from Nigeria, International Journal of Academic Research in Accounting, Finance and Management Sciences, 5(2), $143-150$.

Soderstrom, N. S., \& Sun, K. J. (2007). IFRS Adoption and accounting quality: A review. European accounting review vol.16. no 4, $765-702$.

Street, D. L., Gray, S. J., \& Bryant, S. M. (1999). Acceptance and Observation of International Standards: An Empirical Study of Company Claiming to Comply with IASs. The International Journal of Accounting, 34 (1), 11-48.

Umoren, A. O., \& Enang, E. R. (2015). IFRS Adoption and Value Relevance of Financial Statements of Nigeria Listed Banks. International Journal of Finance and Accounting. 4(1), 1-7.

Yahaya, K. A., Fagbemi, T. O., \& Oyeniyi, K. K. (2015). Effect of international financial reporting standard on financial statements of Nigerian Banks. Journal of Agricultural Economics, Environment and Social Science, 1 (1), 1-29.

Yahaya, O. A., Yusuf, M. J., \& Dania, I. S. (2015). International Financial Reporting Standards' Adoption and Financial Statement Effects: Evidence from Listed Deposit Money Banks in Nigeria. Research Journal of Finance and Accounting, 6, No.12. 